\title{
PENERAPAN E-COMMERSE DALAM PENJUALAN JAMU TRADISIONAL AL-QOMAR
}

\author{
Oleh \\ Juni Iswanto \\ Institut Agama Islam Pangeran Diponegoro Nganjuk \\ juniiswanto@iaipd-nganjuk.ac.id
}

\begin{abstract}
If the first person in marketing his business product must go first to the market, it is not enough there but it becomes a strategic place to offer his merchandise. In addition, some of them need places like shop houses, stalls or other so that the merchandise sells. Of course, all of that requires a lot of energy, time and cost. As the development of technology turned out to be able to change the way of selling. Now traders do not need to come to the market and wait for shops or stalls but simply use online media as a means of marketing. This method is called Electronic Commerce (e-commerce) is the process of buying, selling or exchanging products, services and information through a computer network. Easier, E-commerse is buying and selling activities carried out through electronic media, such as Facebook, Twitter, whats App, web sites and other media. This is what Al-Qomar Traditional Herbal Medicine IKM has done to market its products. Buying and selling without face to face can lead to things that can trigger crime, especially fraud. Therefore, how Islamic law views the E-Commerse Jamu Al Qomar process.
\end{abstract}

Keywords: E-Commerce, Marketing Islam

\begin{abstract}
Abstrak
Jika orang dulu dalam memasarkan produk usahanya harus pergi dulu ke pasar, tidak cukup disitu saja tetapi menjadi tempat yang cukup strategis untuk menawarkan dagangannya. Selain itu, sebagian mereka perlu tempat seperti ruko, lapak atau lainnya agar dagangan laku terjual. Tentu semua itu butuh tenaga, waktu dan biaya banyak. Seiring perkembangan teknologi ternyata mampu merubah cara berjualan. Kini para pedagang tidak perlu datang ke pasar dan menunggu toko atau lapak tapi cukup menggunakan media online
\end{abstract}


sebagai sarana marketing. Cara ini dinamakan Electronic Commerce (e-commerce) adalah proses pembelian, penjualan atau pertukaran produk, jasa dan informasi melalui jaringan computer. Lebih mudahnya $E$ - commerse adalah kegiatan transaksi jual beli yang dilakukan melalui media elektronik, seperti facebook, twitter, whats App, web site dan media lainnya. Hal inilah yang dilakukan IKM jamu Tradisional $\mathrm{Al}$-Qomar untuk memasarkan produknya. Jual beli tanpa tatap muka secara langsung ini dapat menimbulkan hal-hal yang dapat memicu kejahatan khususnya penipuan. Oleh karena itu, bagaimana hukum Islam memandang proses E-Commerse Jamu Al Qomar.

Kata Kunci: E-Commerce, Marketing Islam

\section{Pendahuluan}

Pada saat ini, teknologi informasi berkembang dengan sangat pesat, seiring kebutuhan manusia yang juga terus bertambah. Teknologi memegang peranan yang penting bagi keberlangsungan hidup manusia. Tidak hanya untuk masyarakat saja teknologi juga berperan penting bagi perusahaan perusahaan yang sedang berkembang maupun yang sudah maju.

Industri Kecil Menengah (IKM) Jamu Tradisional Al-Qomar adalah perusahaan yang bergerak di bidang penjualan jamu. Dahulunya perusahaan tersebut hanya memasarkan produknya dari toko ke toko dan melalui website. Seiring dengan perkembangan teknologi perusahaan tersebut mulai menerapkan e-commerce.

Dinamika persaingan bisnis dalam perkembangan dunia teknologi informasi yang semakin maju dan pesat dari waktu ke waktu sudah terasa dampaknya oleh sebagian besar masyarakat dari yang sederhana menjadi modern dan serba cepat sehingga berdampak pada perilaku informasi dalam segala bidang, baik bidang pendidikan, kesehatan, hiburan, sumber informasi, tenaga kerja, dunia bisnis, dan komunikasi tanpa batasan tempat dan waktu, kebutuhan informasi yang lebih cepat dan murah tentunya menuntut para pemberi informasi untuk memiliki sebuah media online, dimana informasi yang disajikan bisa dengan mudah dan cepat didapatkan oleh konsumen informasi. Hal ini dapat dilakukan dengan penggunaan 
internet. Penggunaan internet untuk aktivitas transaksi bisnis dikenal dengan istilah Electronic Commerce (E-Commerce). ${ }^{114}$

Dalam jurnal yang berjudul "E-mail Marketing: Advantages, Disadvantages and Improving Techniques" Fariborzi dan Zahedifard mengatakan bahwa $e$ - commerce merupakan cara organisasi untuk melakukan bisnis, mereka berupaya untuk mendorong perusahaan - perusahaan publik dan swasta untuk mengadopsi $e$-commerce sebagai alat untuk menjadi lebih kompetitif di pasar global. ${ }^{115}$

Menurut Tafsir Ibnu Kasir maksud ayat di atas ialah Allah SAW melarang hamba - hamba-Nya yang beriman memakan harta sebagian mereka terhadap sebagian lainnya dengan bathil, yaitu dengan berbagai macam usaha yang tidak syar'i seperti riba, judi dan berbagai hal serupa yang penuh tipu daya, sekalipun pada lahiriahnya cara-cara tersebut berdasarkan keumuman hukum syar'i, tetapi diketahui oleh Allah dengan jelas bahwa pelakunya hendak melakukan tipu muslihat terhadap riba. Sehingga Ibnu Jarir berkata: "Diriwayatkan dari Ibnu 'Abbas tentang seseorang yang membeli baju dari orang lain dengan mengatakan jika anda senang, anda dapat mengambilnya, dan jika tidak, anda dapat mengembalikannya dan tambahkan satu dirham.” Itu yang difirmankan oleh Allah SWT.

Ayat ini memberikan penjelasan kepada kita, bahwa untuk memeperoleh rizki tidak boleh dengan cara yang batil yaitu yang bertentangan denagan hukum Islam dan dalam jual beli harus didasari saling rela merelakan, tidak boleh menipu, tidak boleh berbohong, dan tidak boleh merugikan kepentingan umum. ${ }^{116}$

${ }^{114}$ Riyadi, Dkk. Implementasi E-Commerce Sebagai Media Penjualan Online. Jurnal Administrasi Bisnis (Jab)|Vol. 29 No. 1 Desember 2015. 2

${ }^{115}$ Fariborzi dan Zahedifard. E-mail Marketing: Advantages, Disadvantages and Improving Techniques. International Journal of e-Education, e-Business, e-Management and e-Learning, Vol. 2, No. 3, June 2012. 232

${ }^{116}$ Runto Hediana dan Ahmad Dasuki Aly. Transaksi Jual Beli Online Perspektif Ekonomi Islam. Fakultas Syari'ah dan Ekonomi Islam IAIN Syekh Nurjati Cirebon. 42 
Dengan mengaplikasikan situs e-commerce pada perusahaan jamu tradisional tersebut maka konsumen akan mengetahui barang atau jamu yang diproduksi. Dari kutipan diatas dapat disimpulkan bahwa toko online atau biasa yang di sebut dengan e-commerce merupakan bagian yang sangat penting dalam pemasaran produk dalam sebuah perusahaan.

Dari permasalahan yang dihadapi oleh Perusahaan Jamu Tradisional Al - Qomar, penerapan electronic commerce ( $e$ commerce) telah menjadikan hubungan yang erat antara produsen dan pelanggan sehingga dalam penerapan $e$ - commerce bisa merambah sampai ke lokasi terpencil, sehingga dapat disimpulkan bahwa perusahaan tersebut membutuhkan sebuah aplikasi toko online yang bisa menampung produk - produk yang ada dalam perusahaan, sehingga dalam memasarkan produknya, perusahaan tersebut tidak terkendala letak geografis serta memberikan kemudahan kepada konsumen dalam mendapatkan informasi maupun dalam membeli produk yang dijual oleh perusahaan dan membantu dalam mempromosikan produk kepada konsumen, sehingga keuntungan yang diperoleh perusahaan tersebut dapat tercapai dengan maksimal.

Pasar jamu tradisional di Indonesia telah menunjukkan pertumbuhan yang signifikan. Banyaknya produk jamu tradisional dan obat-obatan non herbal yang bermunculan akan membuat persaingan pasar semakin ketat. Berikut adalah jenis jamu yang diproduksi oleh Industri Kecil Menengah (IKM) Jamu Tradisional Al-Qomar, yaitu jamu pegel linu, jamu asam urat, jamu mahkota dewa, haba`atus saudak, jamu pace, jamu kencing manis, jamu super jos, jamu pria perkasa dan lain-lain.

\section{Metode Penelitian}

Penelitian ini menggunakan penelitiian lapangan (Field Researh). Pendekatan penelian lapangan (Field Researh) adalah pendekatan yang luas dalam penelitian kualitatif atau sebagai metode untuk mengumpulkan data kualitatif, peneliti berangkat kelapangan untuk mengadakan pengamatan tentang sesuatu fenomena dalam suatu 
keadaan alamiah. ${ }^{117}$ Jenis penelitian yang digunakan adalah penelitian kualitatif yang bersifat deskriptif. Penelitian kualitatif adalah penelitian yang bermaksud untuk memahami fenomena tentang apa yang dialami oleh subyek penelitian misalnya perilaku, tindakan dan lain-lan., secara holistik dan dengan cara penelitian dalam bentuk kata-kata dan bahasa, dan sesuatu konteks yang alamiah dan dengan memanfaatkan berbagai metode alamiah. ${ }^{118}$

Sejalan dengan pendekatan dan jenis penelitian, peneliti bertujuan untuk mengetahui, memahami dan mengungkapkan realitas dalam penerapan E-Commerce dalam Penjualan Jamu Tradisional Al - Qomar di IKM Jamu Tradisional Al - Qomar Pondok Pesantren Sunan Kalijaga Pakuncen, Patianrowo Nganjuk.

Sesuai dengan pendekatan yang digunakan, maka instrument yang dipakai untuk mengumpulkan data adalah peneliti sendiri. Cirri khasnya dari penelitian kualitatif tidak dapat dipisahkan dari pengamatan tetapi peran peneliti yang menentukan semua skenarionya. Dalam penelitian kualitatif peneliti sebagai human instrument, berfungsi menetapkan fokus penelitian, memilih informan sebagai sumber data, melakukan pengumpulan data, menilai kualitas data, analisis data, menafsirkan data, dan membuat kesimpulan atas temuannya. ${ }^{119}$

Peneliti sebagai instrument penelitian dimaksudkan sebagai pewawancara dan pengamat. Sebagai pewawancara peneliti akan mewawancarai Pemilik IKM, karyawan, santri dan konsumen yang berkaitan dengan penelitian yang diteliti. Sebagai pengamat peneliti mengamati hal-hal yang berkaitan dengan penerapan e-commerce di IKM yang diteliti. Peneliti sebagai alat yang utama yang berarti bahwa peneliti harus dapat mengungkapkan makna, berinteraksi terhadap nilai-nilai lokal dimana hal ini tidak bisa dilakukan dengan menggunakan angket, kuesioner dan lainnya melainkan kehadiran

117 Moleong, L.J, Metodologi Penelitian Kualitatif. Bandung: PT. Remaja Rosdakarya, 2012. 26

118 Ibid., 26

119 Dwi Lestari.Kompetensi Paedagogik Guru Pendidikan Agama Islam Dalam Pelaksanaan evaluasi Pembelajaran. Tidak Diterbitkan, Nganjuk: PAI IAI Pangeran Diponegoro, 2013.36 
peneliti dilokasi penelitian mutlak diperlukan sesuai dengan prinsipprinsip penelitian kualitatif. ${ }^{120}$

Data adalah hasil pencatatan peneliti dalam penelitian ini, baik yang berupa fakta atau angka. ${ }^{121}$ Dalam hal ini menulis hasil penelitian dari wawancara dan pengamatan ditambah dengan strategi strategi pemasaran terutama pada penjualan online (E-Commerse). Sumber data adalah subyek dari mana data dapat diperoleh. ${ }^{122}$ Adapun hasil penelitian ini bersumber dari Pemilik Industri Jamu Al - Qomar, karyawan dan konsumen.

Penelitian ini menggunakan analisis data kualitatif. Untuk mengolah data hasil penelitian, peneliti menggunakan metode induktif. Induktif adalah proses dengan mana peneliti mengumpulkan data dan kemudian mengembangkan suatu teori dari data tersebut. Jadi dalam analisis data dengan metode induktif, peneliti berangkat dari kasusyang bersifat khusus berdasarkan pengalaman nyata untuk kemudian dirumuskan menjadi model, konsep, teori, prinsip, atau definisi yang bersifat umum. ${ }^{123}$

\section{Hasil Dan Pembahasan}

\section{A. Strategi Pemasaran Perspektif Islam}

Strategi adalah sebagai sebuah pola yang mendasar dari sasaran yang berjalan dan yang direncanakan, penyebaran sumber daya dan interaksi organisasi dengan pasar, pesaing, dan faktor-faktor lingkungan. Strategi merupakan tindakan yang bersifat incremental (senantiasa meningkat) dan terus menerus serta dilakukan berdasarkan sudut pandang tentang apa yang diharapkan oleh para pelanggan di masa depan. ${ }^{124}$

Dalam konteks Islam, konsep strategi berkaitan erat dengan peristtiwa yang dialami Rasulallah seperti halnya, strategi perang

${ }^{120}$ Ibid....36

121 Suharsimi, Arikunto. Prosedur Penelitian Suatu Pendekatan Praktek.Jakarta: PT. Rineka Cipta.2013.96

${ }^{122}$ Ibid...,107

123 Dwi Lestari.Kompetensi Paedagogik Guru Pendidikan Agama Islam Dalam Pelaksanaan evaluasi Pembelajaran...40

124 Husein Umar, Desai Penelitian Manajemen Strategik, Jakarta: PT Grafindo Persada, 2010.17. 
ataupun strategi bermuamalah. Pada peristiwa perang badar, Allah SWT mewajibkan para muslimin agar tidak pantang mundur dan segera mengatur strategi. Dalam Al - Qur'an Surat Al - Anfal ayat 15 - 16 yang artinya : "Hai orang-orang yang beriman, apabila kamu bertemu dengan orang-orang yang kafir yang sedang menyerangmu, Maka janganlah kamu membelakangi mereka (mundur). Barangsiapa yang membelakangi mereka (mundur) di waktu itu, kecuali berbelok untuk (sisat) perang atau hendak menggabungkan diri dengan pasukan yang lain, Maka Sesungguhnya orang itu kembali dengan membawa kemurkaan dari Allah, dan tempatnya ialah neraka Jahannam. dan Amat buruklah tempat kembalinya." 125

Dalam ayat diatas terdapat makna "berbelok untuk (sisat) perang" yang dapat ditafsirkan sebagai perintah untuk melakukan strategi perang. Dalam ayat tersebut dijelaskan juga besarnya jumlah musuh ( pesaing bisnis) tidak dapat enjadi alasan untuk mundur dalam perang (persaingan bisnis) kecuali untuk mengatur strategi baru.

Selanjutnya mengenai pemasaran adalah keseluruhan sistem yang berhubungan dengan tujuan untuk merencanakan dan menentukan harga sampai dengan mempromosikan dan mendistribusikan barang dan jasa yang bisa memuaskan kebutuhan pembeli actual dan potensial. ${ }^{126}$

Pemasaran Islami adalah sebuah disiplin bisnis strategis yang mengarahkan proses penciptaan, penawaran, dan perubahan values dari satu inisiator kepada stakeholders-nya, yang dalam keseluruhan prosesnya sesuai dengan akad serta prinsip-prinsip al-Qur'an dan Hadis. ${ }^{127}$ Menurut Kertajaya sebagaimana dikutip Bukhari Alma dan Donni Juni Priansa, bahwa secara umum pemasaran Islami adalah strategi bisnis, yang harus memayungi seluruh aktivitas dalam sebuah perusahaan, meliputi seluruh proses, menciptakan, menawarkan,

125 Fahd ibn "Abd al Aziz Al Sa'ud. Al - Quran dan Terjemahannya. Madinah: Mujamma’ Al Malik Fahd Li Thiba'at Al Mushaf Asy Syarif. 2010.

126 Deliyanti Oentoro, Manajemen Pemasaran Modern, Yogyakarta: LaksBang Pressindo, 2010. 1

127 Bukhari Alma dan Donni Juni Priansa, Manajemen Bisnis Syariah: Menanamkan Nilai dan Praktis Syariah dalam Bisnis Kontemporer, Bandung: Alfabeta, hlm. 340. 
pertukaran nilai, dari seorang produsen, atau satu perusahaan, atau perorangan, yang sesuai dengan ajaran Islam. ${ }^{128}$

Hal ini berarti bahwa dalam syariah marketing, seluruh proses, baik proses penciptaan, proses penawaran, maupun proses perubahan nilai (value), tidak boleh ada hal-hal yang bertentangan dengan akad dan prinsip-prinsip muamalah yang Islami. Sepanjang hal tersebut dapat dijamin, dan penyimpangan prinsip-prinsip muamalah Islami tidak terjadi dalam suatu transaksi apapun dalam pemasaran dapat dibolehkan.

Islam memandang bahwa pemasaran sebagai jual beli yang harus dipajang dan ditunjukkan keistimewaan-keistimewaannya dan kelemahan-kelemahan dari barang tersebut agar pihak lain tertarik membelinya. Sesuai dengan Ayal Al Qur'an yang artinya : "Sesungguhnya Allah telah membeli dari orang-orang mukmin diri dan harta mereka dengan memberikan surga untuk mereka. mereka berperang pada jalan Allah; lalu mereka membunuh atau terbunuh. (Itu telah menjadi) janji yang benar dari Allah di dalam Taurat, Injil dan Al Quran. dan siapakah yang lebih menepati janjinya (selain) daripada Allah? Maka bergembiralah dengan jual beli yang telah kamu lakukan itu, dan Itulah kemenangan yang besar."

Dalam sebuah hadits juga disebutkan: "Ketahuilah bahwa surga adalah barang dagangan Allah, dan ketahuilah bahwa barangbarang dari surga mahal harganya." (HR. at-Tirmidzi)

Ada 4 karakteristik pemasaran Islami (syariah marketing) yang dapat menjadi panduan bagi para pemasar sebagai berikut: ${ }^{130}$ Pertama Teistis (rabaniyyah) yakni Salah satu teistis syariah marketing yang tidak dimiliki dalam pemasaran konvensional yang dikenal selama ini adalah sifat yang religius (dinniyah). Kondisi ini tercipta tidak karena keterpaksaan, tetapi berangkat dari kesadaran akan nilai-nilai teistis yang dipandang penting dan mewarnai aktivitas

${ }^{128}$ Ibid., hlm. 343.

129 Fahd ibn "Abd al Aziz Al Sa'ud. Al - Quran dan Terjemahannya. Madinah: Mujamma' Al Malik Fahd Li Thiba'at Al Mushaf Asy Syarif. 2010.

${ }^{130} \mathrm{http}: / /$ makalahqsyamlah.blogspot.co.id/2012/06/manajemenpemasaran-Islam.html. 22:10 03/03/2017 
pemasaran agar tidak terperosok kedalam perbuatan yang dapat merugikan orang lain.

Kedua Etis (akhlaqiyyah), sifat etis ini sebenarnya merupakan turunan dari sifat teistis. Dengan demikian, syariah marketing adalah konsep pemasaran yang sangat mengedepankan nilai-nilai moral dan etika, tidak peduli apapun agamanya. Karena nilai etika adalah nilai yang bersifat universal, yang diajarkan oleh semua agama. Untuk mencapai tujuan tersebut, Allah memberikan petunjuk melalui para rasul-Nya yang meliputi segala sesuatu yang dibutuhkan manusia, baik aqidah, akhlak (moral, etika), maupun syariah. Dua komponen pertama, akidah dan akhlak bersifat konstan, keduanya tidak mengalami perubahan apapun dengan berbedanya waktu dan tempat. Sedangkan syariah senantiasa berubah sesuai dengan kebutuhan dan taraf peradaban manusia, yang berbeda-beda sesuai dengan rasulnya masing-masing.

Ketiga Realistis (al-waqi'iyyah), syariah marketing bukanlah konsep yang eksklusif, fanatis, anti-modernitas, dan kaku. Syariah marketing adalah konsep pemasaran yang fleksibel, sebagaimana keluwesan syariah Islamiyah yang melandasinya. Syariah marketer bukanlah berarti para pemasar itu harus berpenampilan ala bangsa Arab dan mengharamkan dasi karena dianggap merupakan simbol masyarakat barat. Syariah marketer adalah para pemasar profesional dengan penampilan yang bersih, rapi, dan bersahaja, apapun model atau gaya berpakaian yang dikenakannya. Mereka bekerja dengan _profesional dan mengedepankan nilai-nilai religius, kesalehan, aspek moral, dan kejujuran dalam segala aktivitas pemasarannya.

Keempat Humanistis (insaniyyah) adalah bahwa syariah diciptakan untuk manusia agar derajatnya terangkat, sifat kemanusiaannya terjaga dan terpelihara, serta sifat-sifat kehewanannya dapat terkekang dengan panduan syariah. Dengan memiliki nilai humanistis ia menjadi manusia yang terkontrol, dan seimbang (tawazun), bukan manusia yang serakah, yang menghalalkan segala cara untuk meraih keuntungan yang sebesarbesarnya. Bukan menjadi manusia yang bahagia diatas penderitaan orang lain atau manusia yang kering dengan kepedulian sosial. Syariat Islam adalah syariah humanistis (insaniyyah). Syariat Islam diciptakan untuk manusia sesuai dengan kapasitasnya tanpa menghiraukan ras, 
warna kulit, kebangsaan, dan status. Hal inilah yang membuat syariah memiliki sifat universal sehingga menjadi syariat humanistis universal.

\section{B. Pengertian E-Commerce Secara Umum}

Pada saat ini persaingan pasar diberbagai bisnis mengalami perkembangan yang pesat. Dimana, perusahaan harus memasarkan produknya agar perusahaan tersebut mengalami perkembangan dan mengalami keuntungan. Apalagi pada saat ini, teknologi informasi berkembang dengan sangat pesat, seiring kebutuhan manusia yang juga terus bertambah. Teknologi memegang peranan yang penting bagi keberlangsungan hidup manusia. Tidak hanya untuk masyarakat saja teknologi juga berperan penting bagi perusahaan - perusahaan yang sedang berkembang maupun yang sudah maju.

Dinamika persaingan bisnis dalam perkembangan dunia teknologi informasi yang semakin maju dan pesat dari waktu ke waktu sudah terasa dampaknya oleh sebagian besar masyarakat dari yang sederhana menjadi modern dan serba cepat sehingga berdampak pada perilaku informasi dalam segala bidang, baik bidang pendidikan, kesehatan, hiburan, sumber informasi, tenaga kerja, dunia bisnis, dan komunikasi tanpa batasan tempat dan waktu, kebutuhan informasi yang lebih cepat dan murah tentunya menuntut para pemberi informasi untuk memiliki sebuah media online, dimana informasi yang disajikan bisa dengan mudah dan cepat didapatkan oleh konsumen informasi. Hal ini dapat dilakukan dengan penggunaan internet. Dimana transaksi online ini dikenal dengan Electronic Commerce (e-cpmmerce).

E-commerce merupakan prosedur berdagang atau mekanisme jual-beli di internet dimana pembeli dan penjual dipertemukan di dunia maya. E-commerce juga dapat didefinisikan sebagai suatu cara berbelanja atau berdagang secara online atau direct selling yang memanfaatkan fasilitas Internet dimana terdapat website yang dapat menyediakan layanan "get and deliver." 131

${ }^{131} \mathrm{https}: / /$ arya2710.wordpress.com/materi/ E-Commere. 13.18 $(03 / 03 / 2018)$ 
E-commerce merupakan bagian dari e-business, di mana cakupan e-business lebih luas, tidak hanya sekedar perniagaan tetapi mencakup juga pengkolaborasian mitra bisnis, pelayanan nasabah, lowongan pekerjaan dll. Selain teknologi jaringan www, e-commerce juga memerlukan teknologi basis data atau pangkalan data (database), e-surat atau surat elektronik (e-mail), dan bentuk teknologi non komputer yang lain seperti halnya sistem pengiriman barang, dan alat pembayaran untuk e-commerce ini. Pada intinya, $E$ - commerse adalah kegiatan transaksi jual beli yang dilakukan melalui media elektronik, seperti facebook, twitter, whats App, web site dan media lainnya.

\section{E-Commerce Menurut Syariat Islam}

Di dalam bisnis online yang terpenting adalah ketersediaan informasi dan adanya keuntungan. Sebagaimana keterangan dan penjelasan mengenai dasar hukum hingga persyaratan transaksi salam dalam hukum Islam, kalau dilihat secara sepintas mungkin mengarah pada tidak dibolehkannya transaksi secara online, disebabkan ketidakjelasan tempat dan tidak hadirnya kedua pihak yang terlibat dalam tempat. Tapi kalau kita mencoba menelaah kembali dengan mencoba mengkolaborasikan antara ungkapan Al-Qur'an, Hadits dan ijma', dengan sebuah landasan, sebagaimana ungkapan Abdullah bin Mas'ud : ,bahwa apa yang telah dipandang baik oleh muslim maka baiklah dihadapan Allah, akan tetapi sebaliknya. Dan yang paling penting adalah kejujuran, keadilan, dan kejelasan dengan memberikan data secara lengkap, dan tidak ada niatan untuk menipu atau merugikan orang lain. ${ }^{132}$

Salah satu ayat yang mengenai jual beli yang artinya; "Hai orang-orang yang beriman, janganlah kamu saling memakan harta sesamamu dengan jalan yang batil, kecuali dengan jalan perniagaan yang Berlaku dengan suka sama-suka di antara kamu. dan janganlah kamu membunuh dirimu, Sesungguhnya Allah adalah Maha Penyayang kepadamu."

${ }^{132}$ Rodame Monitorir Napitupulu. Pandangan Islam Terhadap Jual Beli Online. Volume 1, No.2, Juli-Desember 2015. 
Dalam Islam e-commerce adalah transaksi jual beli secara yang dilakukan secara online yang sesuai dengan syariat Islam. Jual beli online menjadi benar dan sah menurut syariah Islam, diantaranya merupakan produk halal, produk yang dijual harus memiliki manfaat, produk yang dijual harus dapat diserahkan, kejelasan status penjual, kesesuaian harga dengan kualitas barang DAN kejujuran.

\section{Penerapan dan Pengaruh E-Commerse dalam IKM Jamu Tradisional Al-Qomar}

IKM Jamu Tradisional Al-Qomar Berdiri Pada tahun 1999. Berdirinya IKM Jamu Tradisional Al-Qomar yaitu berawal dari keluh kesah DR. KH. Komari Syaifullah, beliau melihat disekeliling masyarakat Kabupaten Nganjuk pada waktu itu masih banyak pengangguran serta masih banyak anak-anak yang belum bisa baca tulis. Berangkat dari inilah kemudian DR. KH. Komari Syaifulloh mendirikan IKM Jamu tradisional Al-Qomar untuk menyediakan pekerjaan bagi masyarakat yang ada disekitar IKM yang belum bekerja. Kemudian perputaran laba dari IKM ini akan dibuat suatu lembaga pendidikan serta lembaga pelatihan yang nantinya dapat memberikan suatu pendidikan serta pelatihan bagi masyarakat disekitar IKM yang masih belum bisa baca tulis serta bagi masyarakat yang menginginkan belajar berwira usaha atau ketrampilan, mereka bisa belajar di lembaga ini sehingga setelah belajar mereka bisa mandiri dan bisa menjadi pioner-pioner pembangunan di desanya masing-masing.

Saat ini pasar jamu tradisional telah mengalami perkembangan yang sangat pesat. Banyaknya produk jamu tradisional yang bermunculan akan membuat persaingan pasar semakin ketat. Agar suatu perusahaan mampu bersaing dan bertahan maka perusahaan-perusahaan tersebut harus dapat menciptakan produk yang menarik dan tentunya berkualitas, sehingga dapat manarik konsumen untuk memilih produk tersebut.

Salah satu bidang yang terpenting dalam menghadapi persaingan industri adalah pada sektor pemasaran, oleh sebab itu suatu perusahaan harus memiliki strategi pemasaran yang tepat agar dapat memasuki pasar dan dapat menghadapi berbagai kesulitan yang akan dihadapi, sehingga perusahaan mampu bertahan dalam persaingan. 
Salah satu masalah pokok yang menjadi kendala dalam pemasaran adalah banyaknya saingan di dalam pasar itu sendiri baik dari produk sejenis maupun dari produk lain. Hal tersebut merupakan tanggung jawab besar yang harus dimenangkan oleh suatu perusahaan jika ingin tetap eksis di dalam persaingan bisnis. Persaingan yang semakin tajam dan perubahan-perubahan yang terus terjadi harus dapat dijadikan pelajaran oleh manajemen pemasaran agar dapat secara proaktif mengantisipasi perubahan-perubahan yang terjadi baik untuk masa sekarang dan akan datang.

Produk-produk yang dipasarkan dibuat melalui suatu proses yang berkualitas akan memiliki sejumlah keistimewaan yang mampu meningkatkan kepuasan konsumen atas penggunaan produk tersebut. Dengan demikian pelanggan mau dan rela untuk kembali menikmati apa yang ditawarkan oleh perusahaan dan menjadi pelanggan yang setia bagi perusahaan. Sedangkan untuk dapat mendistribusikan kualitas dibidang jasa merupakan hal yang tidak mudah. Oleh karena itu, dalam proses pendistribusian barang kepada konsumen harus ada perhatian penuh dari manajemen pemasaran.

Pengelolaan pengendalian-pengendalian (Managing Controls) yaitu kegiatan-kegiatan yang dilakukan Manajer Sistem Informasi untuk menyakinkan bahwa pengendalian-pengendalian di dalam sistem teknologi informasi masih tetap dilakukan dan masih efektif dalam mencegah ancaman dan gangguan terhadap sistem informasi. Dalam pemasaran barang dapat dilakukan dengan berbagai cara, misalnya melalui media televise, radio, pamphlet, maupun melalui website (online).

Dalam melakukan pemasaran harus memperhatikan bisnis yang dilakukan sesuai dengan syariat islam terutama bisnis online. Dimana produk harus halal, tidak ada riba, saling percaya, tidak ada yang dirugikan dan kedua pihak saling rela. Seperti dalam Al Qur'an dijelaskan "Hai orang-orang yang beriman, janganlah kamu saling memakan harta sesamamu dengan jalan yang batil, kecuali dengan jalan perniagaan yang Berlaku dengan suka sama-suka di antara kamu. dan janganlah kaтu membunuh dirimu[287]; Sesungguhnya Allah adalah Maha Penyayang kepadamu”. Di IKM Jamu Tradisional Al -Qomar menerapkan transaksi e-commerce dalam pemasaran produknya. Transaksi e-commerce dilakukan melalui berbagai media 
diantaranya website, twitter, facebook, dan whats App. Dalam penerapannya IKM jamu Tradisional Al-Qomar ini sesuai dengan prinsip Islam dimana saling rela, jujur, barang sesuai dengan kualitasnya dan sesuai anjuran $\mathrm{Al}$-Qur'an.

\section{Kesimpulan}

E- Commerce (Elektronic Commerce) adalah suatu pembelian, penjualan atau pertukaran produk menggunakan jaringan komputer. $E$ - commerce adalah salah satu media yang digunakan semua kalangan terutama perusahaan terutama dalam memasarkan produknya. ${ }^{133}$ penerapan ini melalui transaksi ini melalui beberapa media sosial, diantaranya melalui website, facebook, twitter, instagram, whats app dan media lainnya.

E-commerce dipandang Islam sebagaimana keterangan dan penjelasan mengenai dasar hukum hingga persyaratan transaksi salam dalam hukum Islam, kalau dilihat secara sepintas mungkin mengarah pada tidak dibolehkannya transaksi secara online, disebabkan ketidakjelasan tempat dan tidak hadirnya kedua pihak yang terlibat dalam tempat. Dalam Islam transaksi $e$ - commerce yang paling penting harus menerapkan kejujuran, keadilan, dan kejelasan dengan memberikan data secara lengkap, dan tidak ada niatan untuk menipu atau merugikan orang lain.

Di IKM Jamu Tradisional Al -Qomar menerapkan transaksi e-commerce dalam pemasaran produknya. Transaksi $e$ - commerce dilakukan melalui berbagai media diantaranya website, twitter, facebook, dan whats App. Dalam penerapan transaksi ini, semua jenis e-commerce digunakan, seperti dari produsen ke konsumen, dari agen kea gen, ataupun agen ke konsumen. Dalam penerapannya IKM jamu Tradisional Al-Qomar ini sesuai dengan prinsip Islam dimana saling rela, jujur, barang sesuai dengan kualitasnya dan sesuai anjuran AlQur'an. Tujuan IKM Jamu Tradisional Al-Qomar penerapan transaksi ini adalah agar produk Jamu ini tidak hanya tersebar di sekiar perusahaan, namun sampai pelosok maupun daerah yang sukar dijangkau. Dengan menerapkan transaksi e-commerce peningkatan

${ }^{133}$ Siregar, Riki R. 2010. Strategi Meningkatkan Persaingan Bisnis Perusahaan dengan Penerapan E-commerce. 
penjualan juga sangat pesat dibanding sebelum menerapkan transaksi e-commerce.

\section{Saran}

Setelah melakukan kajian terhadap penerapan e-commerce dalam penjualan Jamu Tradisional Al - Qomar, maka peneliti menyampaikan saran sebagai berikut :

1. Meskipun IKM Jamu Tradisional Al- Qomar telah menerapkan pemasaran e-commerce, tetapi pemasaran melalui media lainya juga harus tetap dilakukan dan dalam penerapan promosinya harus disesuaikan dengan perkembangan zaman, serta sesuai trending pada saat ini.

2. Meskipun IKM Jamu Tradisional Al - Qomar telah menerapan $e-$ commerce, tetapi juga harus diperhatikan berbagaii bentuk maupun motif aplikasi $e-$ commerce agar lebih menarik konsumen.

\section{Daftar Pustaka}

Abdullah, Thamrin dan Francis Tantri. Manajement Pemasaran. PT.Raja Grafindo Persada, Depok,2012.

Abdurrahman, Nana Herdiana.Manajement Bisnis Syari'ah dan Kewirausahaan. Setia Pustaka ,Bandung, 2013.

Ahmed, Dalbir. Potential E-Commerce Adoption Strategies For Libyan Organization. Volume 1 No. 7,2011

Alma. Buchari. Manajemen Pemasaran dan Pemasaran Jasa, Alfabeta, Bandung, 2011.

Alteza . Muniya. Pengantar Bisnis Teori Dan Aplikasi Di Indonesia. Fakultas Ilmu Sosial dan Ekonomi UN Yogyakarta,2011.

Arikunto ,Suharsimi.Prosedur Penelitian Suatu Pendekatan Praktek. PT. Rineka Cipta, Jakarta, 2013.

Fariborzi dan Zahedifard. E-mail Marketing: Advantages, Disadvantages and Improving Techniques. International Journal of e-Education, e-Business, e-Management and eLearning, Vol. 2, No. 3, 2012. 
Fahd ibn "Abd al Aziz Al Sa'ud. Al - Quran dan Terjemahannya. Madinah: Mujamma' Al Malik Fahd Li Thiba'at Al Mushaf Asy Syarif. 2010.

Fauyhi Eko Nugroho. Perancangan Sistem Informasi Penjualan Online Studi Kasus Tokoku. Vol 7 No 2, 2016.

Ginting, Hartimbul F.Manajement Pemasaran, Yarma Widya ,Bandung,2011.

Hasan, Ali. Marketing Bank Syariah, Ghalia Indonesia Bogor,2010.

Irmawati, Dewi. Pemanfaatan E-Commerce Dalam Dunia Bisnis. Jurnal Ilmiah Orasi Bisnis Edisi Ke-VI, November ,2011.

Jogiyanto..Metodologi Penelitian Bisnis, KPYE IKAPI ,Yogyakarta, 2012.

Lestari, Dwi. Kompetensi Paedagogik Guru Pendidikan Agama Islam Dalam Pelaksanaan evaluasi Pembelajaran, IAI Pangeran

Diponegoro ,Nganjuk. 2013

L.J. Moleong.Metodologi Penelitian Kualitatif. PT. Remaja Rosdakarya, Bandung, 2012

Nugroho. Fauyhi Eko. Perancangan Sistem Informasi Penjualan Online Studi Kasus Tokoku.Jurnal Simetris, Vol 7 No 2 ,November 2016.

Oentoro, Deliyanti. Manajemen Pemasaran Modern, LaksBang Pressindo, Yogyakarta, 2010.

Riyadi, Dkk. Implementasi E-Commerce Sebagai Media Penjualan Online. Jurnal Administrasi Bisnis (Jab)|Vol. 29 No. 1 Desember ,2015.

Rodame Monitorir Napitupulu. Pandangan Islam Terhadap Jual Beli Online. Volume 1, No.2, Juli-Desember, 2015.

Siregar, Riki R. Strategi Meningkatkan Persaingan Bisnis Perusahaan dengan Penerapan E-commerce, 2010

Sule, Erni Trisnawati. Manajement Bisnis Syari'ah, PT. Rafika Aditama, Bandung, 2016.

S. Wacker. Dr. 2012. The American Marketing Association. PT Grafindo Persada, Chicago II volume 18.

Umar . Husein. Desain Penelitian Manajemen Strategik, Jakarta,2010. http://eprints.uny.ac.id/7732/3/BAB\%202-06408144012.pdf. $\underline{(23 / 1 / 2018.19: 22)}$ 